\title{
Experimental studies about the impact of traction sand on urban road dust composition
}

Kupiainen, K.

Elsevier Science B.V.

2003

Kupiainen, K., Tervahattu, H. and Räisänen, M. 2003. Experimental studies about the impact

pÿof traction sand on urban road dust composition. Science of the Total Environment 308: 175184.

http://hdl.handle.net/1975/231

Downloaded from Helda, University of Helsinki institutional repository.

This is an electronic reprint of the original article.

This reprint may differ from the original in pagination and typographic detail.

Please cite the original version. 


\title{
Experimental studies about the impact of traction sand on urban road dust composition
}

\author{
Kaarle Kupiainen $^{\mathrm{a}, \mathrm{b}, *}$, Heikki Tervahattu ${ }^{\mathrm{a}, \mathrm{b}}$, Mika Räisänen ${ }^{\mathrm{c}}$ \\ ${ }^{a}$ Department of Limnology and Environmental Protection, University of Helsinki, P.O. Box 62, Helsinki FIN-00014, Finland \\ ${ }^{\mathrm{b}}$ Nordic Envicon Ltd., Koetilantie 3, Helsinki FIN-00710, Finland \\ ${ }^{\circ}$ Department of Geology and Mineralogy, University of Helsinki, P.O. Box 64, Helsinki FIN-00014, Finland
}

Received 31 May 2002; received in revised form 20 November 2002; accepted 23 November 2002

\begin{abstract}
Traffic causes enhanced $\mathrm{PM}_{10}$ resuspension especially during spring in the US, Japan, Norway, Sweden and Finland, among other countries. The springtime $\mathrm{PM}_{10}$ consists primarily of mineral matter from tyre-induced paved road surface wear and traction sand. In some countries, the majority of vehicles are equipped with studded tyres to enhance traction, which additionally increases road surface wear. Because the traction sand and the mineral matter from the pavement aggregate can have a similar mineralogical composition, it has been difficult to determine the source of the mineral fraction in the $\mathrm{PM}_{10}$. In this study, homogenous traction sand and pavement aggregate with different mineralogical compositions were chosen to determine the sources of $\mathrm{PM}_{10}$ particles by single particle analysis (SEM/EDX). This study was conducted in a test facility, which made it possible to rule out dust contributions from other sources. The ambient $\mathrm{PM}_{10}$ concentrations were higher when traction sand was used, regardless of whether the tyres were studded or not. Surprisingly, the use of traction sand greatly increased the number of the particles originating from the pavement. It was concluded that sand must contribute to pavement wear. This phenomenon is called the sandpaper effect. An understanding of this is important to reduce harmful effects of springtime road dust in practical winter maintenance of urban roads
\end{abstract}

(c) 2002 Elsevier Science B.V. All rights reserved.

Keywords: $\mathrm{PM}_{10}$; SEM/EDX; Mineral dust; Sanding; Paved roads; Fugitive dust; Studded tyres; Aggregate

\section{Introduction}

In Northern latitudes with constant snow coverage during winter months (December-March), high particle concentrations have been observed. High concentrations occur especially during the

*Corresponding author. Tel.: + 358-9-386 6030; fax: +3589-386 94111.

E-mail address:

kaarle.kupiainen@helsinki.fi (K. Kupiainen). spring in urban areas with high traffic volume (Amemiya et al., 1984; Fukuzaki et al., 1986; Noguchi et al., 1995; Kantamaneni et al., 1996; Kukkonen et al., 1999). The particles are deposited in snow, and when snow melts, road surfaces dry out, and a proportion of the dust is resuspended by traffic. Springtime suspended particles form one of the most serious problems regarding air pollution in Finland. This is particularly true when measured levels are compared with the national 
guidelines (Kukkonen et al., 1999; Tiittanen et al., 1999). During these spring conditions, road dust consisting primarily of mineral matter dominates the particulate mass (Pakkanen et al., 2001a,b). A similar phenomenon has been observed in other countries as well, (e.g. Amemiya et al., 1984; Fukuzaki et al., 1986; Noguchi et al., 1995; Kantamaneni et al., 1996). Apart from the discomfort caused by the dust, respirable mineral particles, e.g. aluminosilicates and crystalline quartz have been implicated in human disease with lung cancer as most severe (Puledda et al., 1999; Powell 2002; NIOSH, 2002). Whether these effects are significant in urban conditions is still unknown. Studies of exposure to mineral and resuspension particles have shown evidence of toxicity and a possibility of adverse health effects (Tiittanen et al., 1999; Klockars, 2000; Salonen et al., 2000). However, an epidemiological study by Laden et al. (2000) found no association between increased mortality and fine mineral particle concentrations.

The mineral dust in the particulate mass mainly results from the use of anti-skid methods to enhance traction on snowy or icy road surfaces. Such methods include spreading of traction sand on the road surfaces and equipping tyres with metal studs or a special rubber design, and salting the road to prevent sliding. The traction sand is crushed into smaller particles under the tyres and the pavement aggregate is worn by interaction with the tyres. In Finland, approximately $90 \%$ of the cars have studded tyres, but especially in the urban areas traction sand is widely used in addition. The Finnish National Road Administration has studied pavement wear by studded tyres and evaluated the possible dust problems arising from it, (e.g. Alppivuori et al., 1995). The main hypothesis has been that traction sand is the most important source of the springtime road dust.

The dust problem induced by the use of antiskid methods has been acknowledged also in Japan, Sweden and in the US. In Japan, studies have shown that the use of studded tyres is responsible for elevated particle concentrations during winter and spring (Amemiya et al., 1984; Fukuzaki et al., 1986; Noguchi et al., 1995). Bringfelt et al. (1997) have developed a local $\mathrm{PM}_{10}$ dispersion model for Swedish cities that takes into account an increase in road dust emissions due to the use of anti-skid aggregate and studded tyres. Elevated levels of particulate emissions caused by road sanding have been observed in a study made in the US (Kantamaneni et al., 1996). However, the presence of vehicles with studded tyres was not reported in that study. The US Environmental Protection Agency's AP-42 model gives an approximate guideline to apply a factor of 4 for emissions on roads where sand has been used (Kantamaneni et al., 1996).

The particulate mass problem caused by different anti-skid methods has not been well studied and for only one method at a time. However, these methods are often used in combination. This study seeks to determine the source contributions and relative $\mathrm{PM}_{10}$ concentrations in situations where traction sanding and studded tyres are used together or individually. As the mineralogy of the sanding and pavement aggregates can be very similar, it is very difficult to identify the source of dust. In urban conditions other sources can complicate the situation. This study was conducted in a test facility where spring time temperature conditions could be simulated and other sources of particles besides traction sand and surface wear could be ruled out. The rock materials for the pavement aggregate and traction sand were chosen because it was possible to identify the particles originating from these two sources based on individual particle analysis with SEM/EDX.

\section{Materials and methods}

\subsection{The test conditions}

The test facility (an approx. 180- $\mathrm{m}^{3}$ volume room) was originally designed for testing the bearing capacity of different types of pavement structures. It has also been used in studies of the dust exposure of road maintenance staff (Mustonen and Valtonen, 2000). For this study, the test room was cooled to a temperature of $4{ }^{\circ} \mathrm{C}$ to represent the typical temperature in spring conditions. Two wheels were attached to an electrically powered rotating axle (Fig. 1), with adjustable rotating speed. It was adjusted to move sideways so that the driving space of the tyres was $33 \mathrm{~cm}$. The 


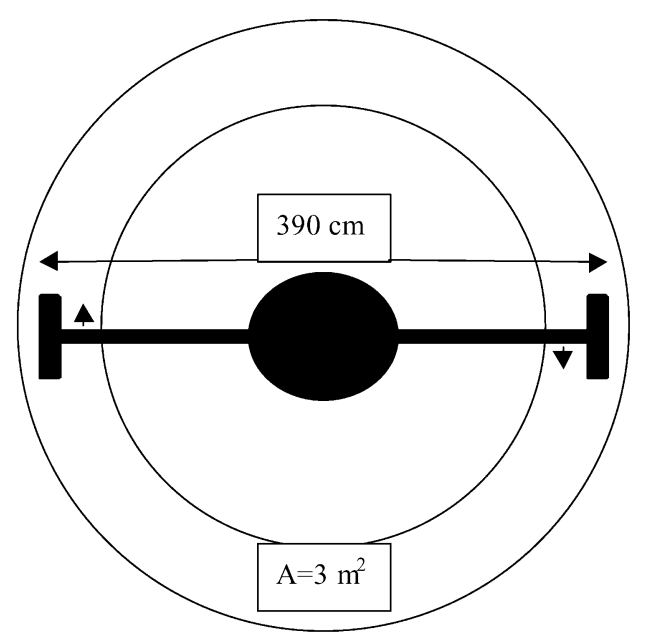

Fig. 1. Schematic picture of the axle system with direction of rotation and the distance between the tyres. The area of the driving space is also shown.

diameter of the test ring was $390 \mathrm{~cm}$. The tests were performed with either studded tyres (Nokian Hakkapeliitta 1, 175/70R13) or with winter tyres lacking studs (Nokian Hakkapeliitta Q, 175/ 70R13). The tyre pressure was 2.0 bar and the weight for each tyre was $300 \mathrm{~kg}$. The driving ring was surrounded with low walls to prevent the traction sand from flying off.

The road surface of the test facility was asphalt concrete 11 (maximum rock size $11 \mathrm{~mm}$ ) with an approximate composition of: $90 \%$ crushed bedrock; 5\% mineral filler (carbonate rock); and 5\% bitumen. This research was based on using antiskid aggregates with a different mineral composition than the pavement aggregate. The most important difference was the content of hornblende (53\% in the asphalt stone and $0 \%$ in the traction sands; Table 1) which was used as a tracer of mineral matter originating from the pavement. Three different rock types, which are also quarried and used in various applications in road building and maintenance, were selected. Granite and diabase were used as anti-skid aggregates and mafic volcanic rock was used as the crushed bedrock aggregate in the asphalt. The detailed mineralogy of the aggregates (Table 1) was analysed with the point-counting method, in which the modal composition (in vol.\%) is determined with a polarising microscope from 1000 equally distributed mineral identifications from a polished thin section of the rock. In addition, blast furnace slag was used in two tests. All of the sands were sieved with a 2-

Table 1

Modal compositions of the aggregates used, based on point-counting analyses of polished thin sections (1000 points/one rock type $)^{\mathrm{a}}$

\begin{tabular}{|c|c|c|c|c|}
\hline Mineral type & $\begin{array}{l}\text { Mafic } \\
\text { volcanic rock } \\
\text { (asphalt) }\end{array}$ & $\begin{array}{l}\text { Granite } \\
\text { (traction } \\
\text { sand 1) }\end{array}$ & $\begin{array}{l}\text { Diabase } \\
\text { (traction } \\
\text { sand 2) }\end{array}$ & Chemical formula \\
\hline Quartz & 0 & 30.4 & 0 & $\mathrm{SiO}_{2}$ \\
\hline K-feldspar & 0 & 29.6 & 0 & $\mathrm{KalSi}_{3} \mathrm{O}_{8}$ \\
\hline Plagioclase & 29.4 & 32.4 & 57.4 & $(\mathrm{Na}, \mathrm{Ca}) \mathrm{Al}(\mathrm{Si}, \mathrm{Al}) \mathrm{Si}_{2} \mathrm{O}_{8}$ \\
\hline Hornblende & 53 & 0 & 0 & $\mathrm{Ca}_{2}(\mathrm{Mg}, \mathrm{Fe})_{4} \mathrm{Al}\left(\mathrm{Si}_{7} \mathrm{Al}\right) \mathrm{O}_{22}(\mathrm{OH}, \mathrm{F})_{2}$ \\
\hline Biotite & 0 & 5.9 & 3.8 & $\mathrm{~K}(\mathrm{Mg}, \mathrm{Fe})_{3}(\mathrm{Al}, \mathrm{Fe}) \mathrm{Si}_{3} \mathrm{O}_{10}(\mathrm{OH}, \mathrm{F})_{2}$ \\
\hline Muscovite & 0 & 0.6 & 0 & $\mathrm{KAl}_{2}\left(\mathrm{AlSi}_{3} \mathrm{O}_{10}\right)(\mathrm{OH}, \mathrm{F})_{2}$ \\
\hline Olivine & 0 & 0 & 17.5 & $(\mathrm{Mg}, \mathrm{Fe})_{2} \mathrm{SiO}_{4}$ \\
\hline Clinopyroxene & 0 & 0 & 17.3 & $(\mathrm{Ca}, \mathrm{Mg}, \mathrm{Fe})_{2} \mathrm{Si}_{2} \mathrm{O}_{6}$ (Augite) \\
\hline Chlorite (group) & 1.4 & 0.3 & 0 & $(\mathrm{Mg}, \mathrm{Fe}, \mathrm{Al})_{6}(\mathrm{Al}, \mathrm{Si})_{4} \mathrm{O}_{10}(\mathrm{OH})_{8}$ \\
\hline Epidote & 0 & 0.2 & 0 & $\mathrm{Ca}_{2}(\mathrm{Al}, \mathrm{Fe}) \mathrm{Al}_{2} \mathrm{O}\left(\mathrm{SiO}_{4}\right)\left(\mathrm{Si}_{2} \mathrm{O}_{7}\right)(\mathrm{OH})$ \\
\hline $\begin{array}{l}\text { Kummingtonite- } \\
\text { grunerite }\end{array}$ & 12.8 & 0 & 0 & $(\mathrm{Mg}, \mathrm{Fe})_{7} \mathrm{Si}_{8} \mathrm{O}_{22}(\mathrm{OH})_{2}$ \\
\hline Oxides & 3.2 & 0.5 & 4 & $\begin{array}{l}\mathrm{Fe}_{3} \mathrm{O}_{4} \text { (Magnetite) } \\
\mathrm{FeTiO}_{3} \text { (Ilmenite) }\end{array}$ \\
\hline Carbonate & 0.2 & 0 & 0 & $\left(\mathrm{CO}_{3}\right)$-group \\
\hline
\end{tabular}

${ }^{a}$ All figures are given as percentages. 
Table 2

The test descriptions ${ }^{\mathrm{a}}$

\begin{tabular}{|c|c|c|c|c|}
\hline Test & Tyre & Sand type & $\begin{array}{l}\text { Amount of } \\
\text { sand }\left(\mathrm{dm}^{3}\right)\end{array}$ & Other \\
\hline No. 1 & Studded S01 & - & 0 & Day 1 \\
\hline No. 2 & Studded GS2 & Granite & 2 & Day 2 \\
\hline No. 3 & No studs GN2 & Granite & 2 & Day 2 \\
\hline No. 4 & Studded CS2 & Blast furnace slag & 2 & Day 3 \\
\hline No. 5 & Studded CS4 & Blast furnace slag & 4 & Day 3 \\
\hline No. 6 & Studded GS2s & Granite & 2 & Day $4($ speed $25 \mathrm{~km} / \mathrm{h})$ \\
\hline No. 7 & Studded DS2 & Diabase & 2 & Day 5 \\
\hline No. 8 & Studded DS4 & Diabase & 4 & Day 5 \\
\hline No. 9 & Studded GS $2 x$ & Granite & 2 & $\begin{array}{l}\text { Day } 6 \text { (traction sand: } \\
<2 \text {-mm fraction } 43 \%)\end{array}$ \\
\hline No. 10 & Studded GS4 & Granite & 4 & Day 6 \\
\hline No. 11 & Studded DS2 & Diabase & 2 & Day 7 \\
\hline No. 12 & No studs DN2 & Diabase & 2 & Day 7 \\
\hline No. 13 & No studs NO & - & 0 & Day 8 \\
\hline No. 14 & Studded S02 & - & 0 & Day 8 \\
\hline
\end{tabular}

${ }^{a}$ Driving speed was $15 \mathrm{~km} / \mathrm{h}$, unless mentioned otherwise.

$\mathrm{mm}$ sieve. The $<2-\mathrm{mm}$ fraction for granite was $20.3 \%$, for diabase $0.3 \%$ and for the clinker $0.4 \%$. One sample (GS2x) was not sieved for these tests and its $<2-\mathrm{mm}$ fraction was $43 \%$.

The tests were conducted during a period of 7 days, one test in the morning and one in the afternoon. The tests are shown in Table 2 and the amount of sand dispersed in Table 3. The short distance between the wheels and the rotating motion result in a grinding effect that is rarely found in normal street conditions. Therefore, we used relatively low speeds $\left(15-25 \mathrm{~km} \mathrm{~h}^{-1}\right)$ in the tests. After each test, the dust was allowed to settle for 30-45 $\mathrm{min}$ and, after that, the room was vacuumed and ventilated. The background concentration of particles was measured each morning before the tests and once between tests. All background concentrations were $75-90 \%$ lower than the test concentrations.

\subsection{The sampling and analysis}

Ambient particles were collected on polycarbonate filters with a high-volume particle sampler $\left(\mathrm{PM}_{10}\right.$-gravimetric Wedding \& Associates Sampler). The inlet was at a height of approximately $2.5 \mathrm{~m}$. Each test took $1 \mathrm{~h}$, which was also the length of the sampling time.
The elemental composition of individual particles was studied with a scanning electron microscope (SEM-ZEISS DSM 962) coupled with an energy dispersive X-ray microanalyzer (EDXLINK ISIS with ZAF-4 measurement program). This instrumentation has been used in individual particle studies, (e.g. Mamane et al., 1980; Kasparian et al., 1998; Ganor et al., 1998; Paoletti et al., 1999; Breed et al., 2002). The SEM/EDX samples were prepared by pressing a tape (Scotch Ruban Adhesive) attached to an aluminum plate onto the filter surface covered with particles. A minimum of two samples from each filter was made. The samples were sputtered with carbon (Agar SEM Carbon Coater) to make the sample surface conductive. The accelerating voltage was $20 \mathrm{kV}$. The total X-ray count rate was calibrated

Table 3

The amount of dispersed traction sand

\begin{tabular}{lllc}
\hline Sand & $\begin{array}{l}\text { Volume } \\
\left(\mathrm{dm}^{3}\right)\end{array}$ & $\begin{array}{l}\text { Mass } \\
(\mathrm{g})\end{array}$ & $\begin{array}{l}\text { Mass/area } \\
\left(\mathrm{g} / \mathrm{m}^{2}\right)\end{array}$ \\
\hline Granite & 2 & 2798 & 926 \\
& 4 & 5596 & 1853 \\
Diabase & 2 & 3190 & 1056 \\
& 4 & 6379 & 2112 \\
Blast furnace & 2 & 2501 & 828 \\
$\quad$ slag & 4 & 5002 & 1656 \\
\hline
\end{tabular}




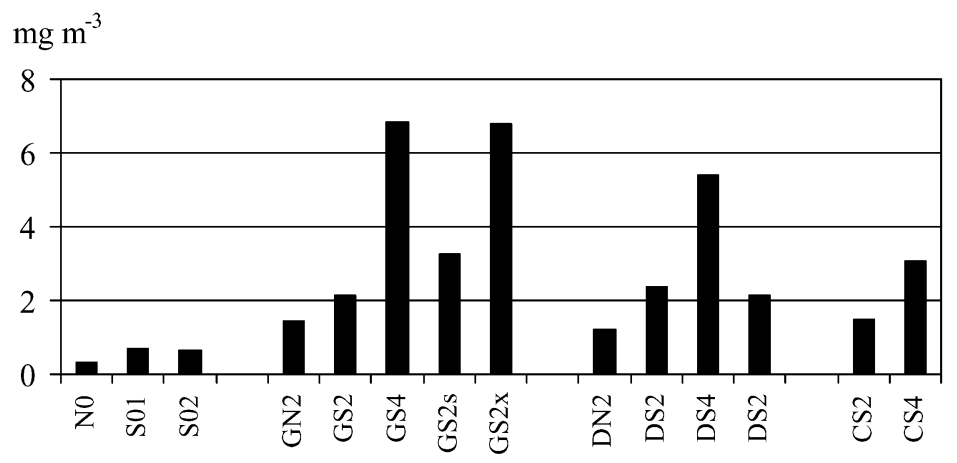

Fig. 2. Ambient mass concentrations $\left(\mathrm{mg} \mathrm{m}^{-3}\right)$ in individual tests. For abbreviations see Table 2, tyre.

to 1500 counts $\mathrm{s}^{-1}$ with cobalt. From each particle an X-ray spectrum was collected with a preset time of $15 \mathrm{~s}$.

The elemental composition of 100-150 randomly selected particles were analysed and recorded with ZAF-4 from each filter. Particles were classified according to the chemical composition. The accuracy of the classification was studied by analysing 500 particles from one sample (GS2) and dividing it into 100 subsamples, which were then compared with each other. The S.D. of the individual classes varied between 0.5 and 4.9. The shape and size of the particles were recorded and the EDX spectrum was measured and saved with ZAF-4. The elemental weight percentages of Al, $\mathrm{Ca}, \mathrm{Cl}, \mathrm{Fe}, \mathrm{K}, \mathrm{Mg}, \mathrm{Na}, \mathrm{O}, \mathrm{S}, \mathrm{Si}$ and $\mathrm{Ti}$ for each particle were calculated. If other elements were clearly observed, their presence was also recorded. The ZAF correction method assumes flat samples. This is rarely the case with complex sized and shaped particles and the atomic concentration may, therefore, be biased (Paoletti et al., 1999). As in the case of Paoletti et al. (1999), the particle types were determined by distinguishing the presence and proportional concentrations of the typical elements, (e.g. for mineral types, see Table 1). This classification could be made with good confidence.

Particles with a geometric diameter below $1 \mu \mathrm{m}$ were ignored from the analysis. This was thought to be the lowest limit to obtain reliable results from individual particles with this technique (Jambers et al., 1995). Thus, a limit did not cause problems for the study because the main focus was on mineral particles that are rarely below 1 $\mu \mathrm{m}$ in diameter.

\section{Results}

\subsection{The particulate mass concentrations}

The $\mathrm{PM}_{10}$ mass concentrations are shown in Fig. 2 and the abbreviations are explained in Table 2. Without traction sand (S01, S02 N0) the $\mathrm{PM}_{10}$ concentrations were much lower than with traction sand. Approximately twice as much $\mathrm{PM}_{10}$ dust was formed with the studded tyres than with the non-studded tyres. This did not seem to depend on traction sand $(\mathrm{S} 0 / \mathrm{N} 0=2.0, \mathrm{GS} 2 / \mathrm{GN} 2=1.5, \mathrm{DS} 2 /$ $\mathrm{DN} 2=2.0$ ). The use of traction sand raised concentrations in every case. The amount of sand dispersed correlated with the $\mathrm{PM}_{10}$ concentrations (Fig. 3). The deviation is suspected to have been caused in part by difference in the properties of the rocks. The test with the $43 \%<2-\mathrm{mm}$ fraction raised the $\mathrm{PM}_{10}$ concentration over 10 -fold compared to the test without sand $(\mathrm{GS} 2 x / \mathrm{S} 0=10.7)$ and three-fold compared to the test with the $20.3 \%$ $<2$-mm fraction (GS2x/GS2=3.2). The particle concentration at a higher speed $\left(25 \mathrm{~km} \mathrm{~h}^{-1}\right)$ was 1.5 times higher than the concentration at $15 \mathrm{~km}$ $\mathrm{h}^{-1}(\mathrm{GS} 2 s / \mathrm{GS} 2=1.5)$.

Emission factors for $\mathrm{PM}_{10}$ particles were estimated by assuming that the PM concentration is distributed equally in the room. In the tests without traction sand, the emission factor was 0.01 for non-studded and $0.02 \mathrm{~g} \mathrm{~km}^{-1}$ for studded tyres. 


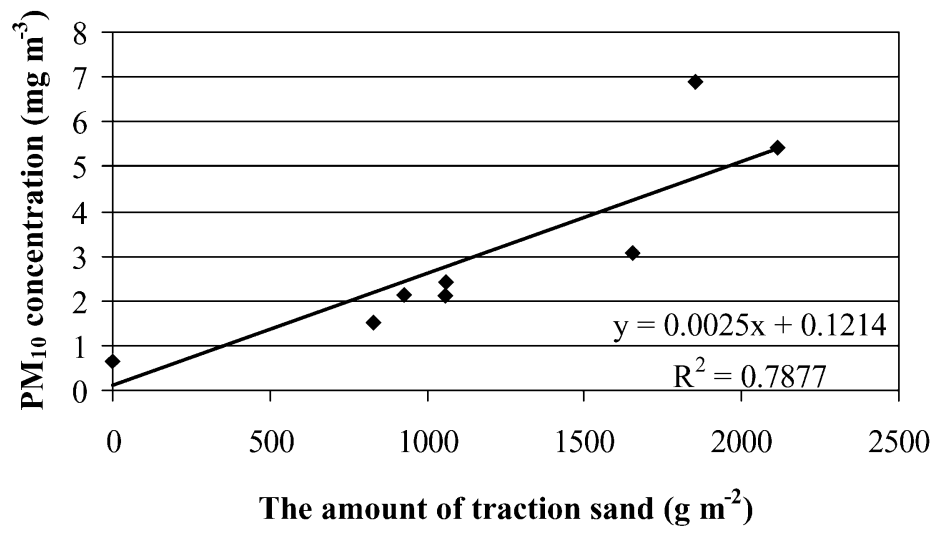

Fig. 3. The correlation between ambient $\mathrm{PM}_{10}$ concentrations and the amount of traction sand used for the studded tyres.

The use of traction sanding increased the emission factors. The emission factors with $900-\mathrm{g} \mathrm{m}^{-2}$ sand were $0.03-0.05 \mathrm{~g} \mathrm{~km}^{-1}$. The same amount of aggregate with $<2-\mathrm{mm}$ sand grains increased the emission factor to $0.16 \mathrm{~g} \mathrm{~km}^{-1}$. The higher speed $\left(25 \mathrm{~km} \mathrm{~h}^{-1}\right)$ did not significantly affect the emission factor. The emissions with studded tyres were somewhat higher than with non-studded also in the sanded tests. The emission factor with $1800-\mathrm{g}$ $\mathrm{m}^{-2}$ sand and studded tyres were $0.07-0.16 \mathrm{~g}$ $\mathrm{km}^{-1}$.

The results from this study are at the lower end of the large range of emission factor estimates found in previous studies for paved road dust (see Table 4) (Claiborn et al., 1995; Kantamaneni et al., 1996; Bringfelt et al., 1997; Venkatram et al., 1999). It is possible that the PM did not disperse equally to the test room as assumed which might lead to an underestimation of the emission factor. It is also obvious that street side conditions cannot be totally simulated in laboratory experiments like these: (1) other sources than road abrasion components were excluded in our tests. They may have a measurable contribution to road dust in

Table 4

A comparison of emission factors $\left(\mathrm{g} \mathrm{km}^{-1}\right)$ for road dust

\begin{tabular}{lll}
\hline & $\begin{array}{l}\mathrm{PM}_{10} \text { emission factor estimate } \\
\left(\mathrm{g} \mathrm{km}^{-1}\right)\end{array}$ & Remarks \\
\hline This study $^{\mathrm{a}}$ & $0.01-0.02$ & Without traction sand \\
& $0.03-0.05$ & With $900 \mathrm{~g} \mathrm{~m}^{-2}$ traction sand \\
& 0.16 & With $900 \mathrm{~g} \mathrm{~m}^{-2}$ traction sand (with <2-mm sand grains) \\
Bringfelt et al. (1997) & $0.07-0.16$ & With $1800 \mathrm{~g} \mathrm{~m}^{-2}$ traction sand \\
Claiborn et al. $(1995)^{\mathrm{c}}$ & 0.05 & $0-19 \mathrm{~km} \mathrm{~h}^{-1}$ \\
Kantamaneni et al. $(1996)^{\mathrm{d}}$ & 0.28 & $19-28 \mathrm{~km} \mathrm{~h}^{-1}$ \\
& $0.5-34$ & Paved road resuspension \\
Venkatram et al. $(1999)^{\mathrm{e}}$ & $0.4-2$ & Without traction sand \\
\hline
\end{tabular}

a Test conditions to represent road abrasion by a light duty car, speed $15-25 \mathrm{~km} \mathrm{~h}^{-1}$.

${ }^{\mathrm{b}}$ Light duty vehicles.

${ }^{\mathrm{c}}$ A field study, roads and streets with varying traffic volume.

${ }^{\mathrm{d}}$ A field study, four-lane street, sand (predominant $0.95 \mathrm{~cm}$ size distribution) dispersed $12 \mathrm{~h}$ prior to sampling.

${ }^{\mathrm{e}}$ A freeway and three major streets. 


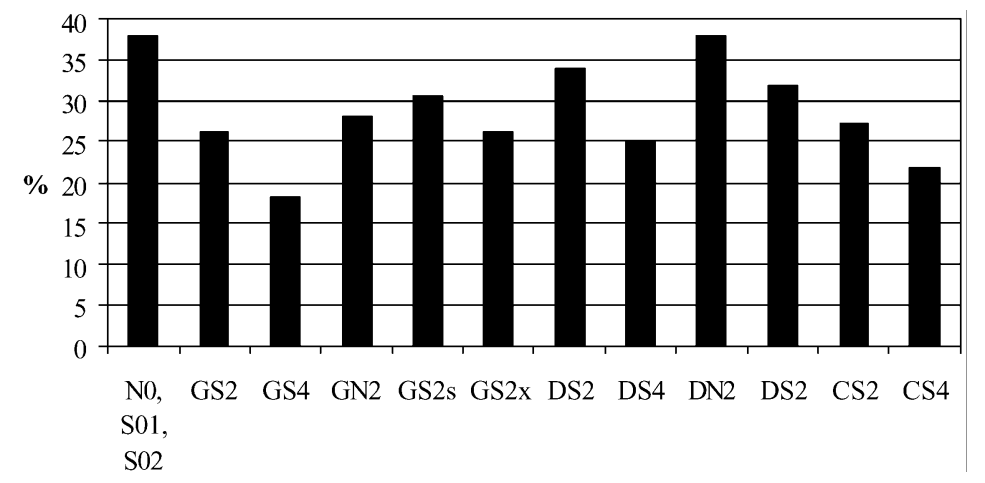

Fig. 4. The abundance $(\%)$ of hornblende in the $\mathrm{PM}_{10}$ samples. For abbreviations see Table 2, tyre.

field conditions (Rogge et al., 1993). (2) Low speeds $\left(15-25 \mathrm{~km} \mathrm{~h}^{-1}\right)$ were used during the tests. Higher speeds also increase the road dust emissions (Bringfelt et al., 1997; Kuhns et al., 2001). (3) Emission factors for heavy-duty vehicles were not measured in our study, e.g. Bringfelt et al. (1997) have reported higher emissions for heavy-duty vehicles than for light duty and they may contribute to the emission estimates made in field conditions.

Despite the uncertainties, it is possible to estimate the relative effect of traction sanding on $\mathrm{PM}_{10}$ emissions. In the field study by Kantamaneni et al. (1996), road sanding increased the emission factor on average 1.4-fold. In the US Environmental Agency's AP-42 model an approximate guideline for emissions on roads with traction sand has been to apply a factor of 4 (ref. from Kantamaneni et al., 1996). In this study the emissions increased three- to eight-fold as a function of sand dispersed (with $900 \mathrm{~g} \mathrm{~m}^{-2}$ and $1800 \mathrm{~g} \mathrm{~m}^{-2}$ sand, respectively Fig. 3).

It can be concluded that the type of tyre, the amount of sand dispersed and the properties of the sanding material all affected the $\mathrm{PM}_{10}$ concentrations. With studded tyres more $\mathrm{PM}_{10}$ dust was formed than by winter tyres without studs. For more generalised conclusions about the effect of the tyre, studies with a larger variety of designs are needed. An important factor was the spreading of traction sand, which significantly raised the $\mathrm{PM}_{10}$ concentrations. The concentrations correlated with the amount of sand used. The share of small size fractions in the sanding material also raised the PM concentration.

\subsection{Composition of the $P M_{10}$ dust}

The amount of dust originating from traction sand and from asphalt was studied by counting the fraction of different mineral types in the $\mathrm{PM}_{10}$ dust samples and comparing these fractions to the mineralogy of the rocks. The most important difference between aggregates was that the sanding materials did not contain hornblende, which was the most abundant mineral type in the mafic volcanic rock of the asphalt aggregate (Table 1).

Since all the hornblende must originate from the asphalt aggregate, its abundance was used as a basis to study the sources of the particles. The fraction of PM originating from the asphalt was calculated by the difference from the abundances in the tests with and without sanding (Fig. 4). It was observed that the mineralogy of the mafic volcanic rock is not exactly representative of the shares of different minerals in the airborne dust (geological variation at the quarry). Consequently, the tests without the sand ( $\mathrm{S} 01, \mathrm{~S} 02 \mathrm{~N} 0$ ) were used as the basis for calculations instead of the mineralogy.

In addition, other particle classes were observed that originated from other sources than aggregates. Class 120 (particles with $\mathrm{Na}-\mathrm{Mg}-\mathrm{Al}-\mathrm{Si}-\mathrm{S}-\mathrm{K}-$ $\mathrm{Ca}-\mathrm{Fe}$, often also $\mathrm{C}$ ) was suspected to be either a bitumen/mineral mixture from asphalt filler or particles from tyres (Rauterberg-Wulff et al., 1995; 


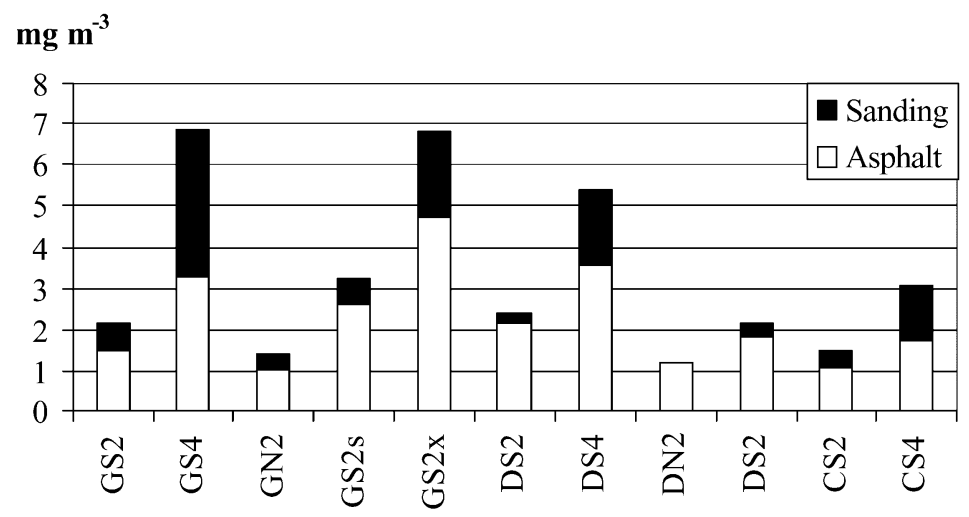

Fig. 5. The average shares of the $\mathrm{PM}_{10}$ from the asphalt and the traction sand. For abbreviations see Table 2, tyre.

Camatani et al., 2001). The share ranged from $1 \%$ (GS2) to $9 \%$ (DS2). The carbonates, ranging from not detected in GN2 to $6 \%$ in DN2, probably came from the filler material.

Using only the particle concentration data would lead to the conclusion that the $\mathrm{PM}_{10}$ dust originates mainly from traction sanding. A compositional analysis of the dust by SEM/EDX showed that a large percentage of the particles contained hornblende and thus, must originate from the asphalt (Table 1). It was concluded from the analyses of the particle concentrations and the analyses of the particle chemistry, that the traction sand is not only crushed into small $\mathrm{PM}_{10}$ particles but also increases the asphalt pavement wear. Road sanding increases the $\mathrm{PM}_{10}$ concentrations but the sources of the particles are both the sanding material and the road pavement. This phenomenon was named 'the sandpaper effect'.

The share from the asphalt ranged from 36\% (GS4) up to $100 \%$ (DS2 and DN2), with the average of all tests being $74 \%$. In Fig. 5, the averages of individual tests were combined with the concentration data (Fig. 2). The more sand was used, the more particles originated from the sanding material (GS4/GS2, DS4/DS2, CS4/ CS2). The traction sand with the higher $<2-\mathrm{mm}$ fraction (GS2x) did not result in a higher share of $\mathrm{PM}_{10}$ dust from the sanding material. The increase in speed (GS2s) raised the share of dust originating from the asphalt. It is important to note that in the tests using tyres without studs (GN2, DN2) the sandpaper effect was also significant.

The rock properties affect the $\mathrm{PM}_{10}$ concentrations. Based on the averages in our tests, the diabase seemed to result in lower $\mathrm{PM}_{10}$ concentrations but had a larger sandpaper effect than the granite (Fig. 5). Räisänen et al. (2002) are preparing a more detailed study of the geological and mechanical properties of anti-skid and asphalt aggregates. That study is based mainly on the same materials and data as this one. In order to make general conclusions about the connection between the rock properties and the PM-concentrations, more detailed studies with more rock types included have to be conducted.

\section{Discussion and conclusions}

The problem of the high springtime particle concentrations caused by snow and ice control methods has been acknowledged in several countries (Amemiya et al., 1984; Fukuzaki et al., 1986; Noguchi et al., 1995; Kantamaneni et al., 1996; Bringfelt et al., 1997; Kukkonen et al., 1999). The mineral dust originating from the asphalt pavement aggregate or the traction sand has been identified to be the main component of the PM (Amemiya et al., 1984; Fukuzaki et al., 1986; Noguchi et al., 1995; Kantamaneni et al., 1996; Kukkonen et al., 1999; Pakkanen et al., 2001a,b). Previous studies have focused only on the effects caused by the 
use of only one of the anti-skid methods, either the traction sand (Kantamaneni et al., 1996) or studded tyres (Amemiya et al., 1984; Fukuzaki et al., 1986; Noguchi et al., 1995). To the knowledge of the authors, the present study is the first one to take the combined effect of these two methods into account.

The results of the present study are interesting from the point of view of the 1999 European Union's legislation on air quality. In the cities of Northern member states including Finland and Sweden, the springtime road dust can cause the $\mathrm{PM}_{10}$ concentrations to exceed the European Union's new air quality limit values for thoracic particles $\left(\mathrm{PM}_{10}\right)$ given in the European Council Directive, 1999. If the limit values are exceeded, a member state must implement action plans to reach the limit value. However, the member state can designate areas where the limit values are exceeded due to the resuspension of particulates following the winter sanding of roads.

The results of this study show that when both traction sand and studded tyres were used, the use of traction sand increased the concentrations of $\mathrm{PM}_{10}$, which might support the dominant role of sanding material in the dust. However, a study of the particle chemistry showed that a significant part of the particulate matter came from asphalt. This result indicates that the pavement wear is strongly increased by the grinding impact of sand under the tyres, which produces dust also from the asphalt aggregate. This phenomenon was named the sandpaper effect. Its understanding is important to reduce harmful effects of springtime road dust in practical winter maintenance of urban roads. Dust emissions an the sandpaper effect were dependent on several factors, such as the mechanical and mineralogical properties of both the sanding and pavement aggregates, the quantity of traction sand used, the size distribution of the sand grains as well as the type of tyres.

\section{Acknowledgments}

The authors would like to thank the following people: Lars Forstén and Matti Mertamo from Lemminkäinen Ltd. for the construction of the asphalt, as well as for the use of their laboratory facilities and their assistance in preparing the sanding aggregates. Timo Blomberg, Tapio Kärkkäinen and Kai Hämäläinen from Fortum Corp. are acknowledged for their assistance in using the test facility, Tero Humaloja, Tarja Koskentalo and Päivi Aarnio from YTV for the use of particle collectors and Timo Paavilainen from YIT, Jari Mustonen from Häme Polytechnic and Veli Suominen from the Geological survey of Finland for their valuable advice. This study, which was part of the MOBILE2 research program, was funded by the Technical Research Center Finland, the Ministry of Transport and Communications, Ministry of the Environment, the Finnish Road Administration, the Helsinki Metropolitan Council (YTV) and Licentia Ltd. M. Räisänen acknowledges support received from the Graduate School in Rock Engineering and Foundation for Research of Natural Resources in Finland.

\section{References}

Alppivuori K., Leppänen A., Anila M., Mäkelä K. Road traffic in winter. Summary of publications in the research program. FinnRA Reports 57. Finnish National Road Administration, Traffic Services. Helsinki, Finland, (1995). pp. 57.

Amemiya S, Tsurita Y, Masuda T, Asawa A, Tanaka K, Katoh $\mathrm{T}$, Mohri M, Yamashina T. Investigation of environmental problems caused by studded tyres of automobiles using PIXE. Nucl Instrum Methods Phys Res 1984;B3:516-521.

Breed CA, Arocena JM, Sutherland D. Possible sources of $\mathrm{PM}_{10}$ in Prince George (Canada) as revealed by morphology an in situ chemical composition of particulate. Atmos Environ 2002;36:1721-1731.

Bringfelt B., Backström H., Kindell S., Omstedt G., Persson C., Ullestig A. Calculations of $\mathrm{PM}_{10}$ concentrations in Swedish cities-modelling of inhalable particles. SMHI RMK No. 76. Swedish Meteorological and Hydrological Institute. Norrköping, Sweden. (1997). pp. 77.

Camatani M., Crosta GF., Cancetti S., Regazzoni C. Tyre debris in the environment: preliminary results about characterization, identification and process analysis. Third International Conference on Urban Air Quality, March (2001). pp. 1-4.

Claiborn C, Mitra A, Adams G, Bamesberger L, Allwine G, Kantamaneni R, Lamb B, Westberg H. Evaluation of $\mathrm{PM}_{10}$ emission rates from paved and unpaved roads using tracer techniques. Atmos Environ 1995;29(10):1075-1089.

European Council Directive 1999/30/EC.

Fukuzaki N, Yanaka T, Urushiyama Y. Effects of studded tyres on roadside airborne dust pollution in Niigata, Japan. Atmos Environ 1986;20(2):377-386. 
Ganor E, Levin Z, Van Grieken R. Composition of individual aerosol particles above the Israelian Mediterranean coast during the summer time. Atmos Environ 1998;32(9):16311642 .

Jambers W, De Bock L, Van Grieken R. Recent advances in the analysis of individual environmental particles. A review. Analyst 1995;120:681-692.

Kantamaneni R, Adams G, Bamesberger L, Allwine E, Westberg $\mathrm{H}$, Lamb B, Claiborn $\mathrm{C}$. The measurement of roadway $\mathrm{PM}_{10}$ emissions rates using atmospheric tracer ratio techniques. Atmos Environ 1996;30(24):4209-4223.

Kasparian J, Frejafon E, Rambaldi P, Yu J, Vezin B, Wolf JP, Ritter P, Viscardi P. Characterization of urban aerosols using SEM-microscopy, X-ray analysis and Lidar Measurements. Atmos Environ 1998;32(17):2957-2967.

Klockars M. The effect of surface properties of mineral dusts on their ability to induce inflammatory response in the lungs. Proceedings SYTTY2. The Mid-term Symposium of the Finnish Research Programme on Environmental Health 29-30 March, 2000 Helsinki, Finland. Publications of the Finnish Research Programme on Environmental Health SYTTY 2000;1:146-149.

Kuhns H, Etyemezian V, Landwehr D, MacDougall C, Pitchford M, Green M. Testing re-entrained aerosol kinetic emissions from roads (TRAKER): a new approach to infer silt loading on roadways. Atmos Environ 2001;35:28152825.

Kukkonen J, Salmi T, Saari H, Konttinen M, Karstasenpää R. Review of urban air quality in Finland. Boreal Environ Res 1999;4:55-65.

Laden F, Neas LM, Dockery DW, Schwartz J. Association of fine particulate matter from different sources with daily mortality in six US cities. Environ Health Perspect 2000;108(10):941-947.

Mamane Y, Ganor E, Donagi AE. Aerosol composition of urban and desert origin in the eastern Mediterranean. I. Individual particle analysis. Water Air Soil Pollut 1980;14:29-43.

Mustonen J., Valtonen J. Katujen kunnossapitotyöntekijöiden pölyaltistuksen vähentäminen katujen pölynpoistossa (in Finnish). Helsinki University of Technology, Internal report, Otaniemi, Finland. (2000). pp. 25.

National Institute for Occupational Safety and Health (NIOSH). Health effects of occupational exposure to respirable crystalline silica. DHHS (NIOSH) Publication No 2002-129, Cinncinati, USA. (2002). pp. 127.
Noguchi I, Kato T, Akiyama M, Otsuka H, Matsumoto Y. The effect of alkaline dust decline on the precipitation chemistry in northern Japan. Water Air Soil Pollut 1995;85:23572362 .

Pakkanen TA, Loukkola K, Korhonen CH, Aurela M, Mäkelä T, Hillamo RE, Aarnio P, Koskentalo T, Kousa A, Maenhaut W. Sources and chemical composition of atmospheric fine and coarse particles in the Helsinki area. Atmos Environ 2001a;35:5381-5391.

Pakkanen TA, Kerminen V-M, Korhonen CH, Hillamo RE, Aarnio P, Koskentalo T, Maenhaut W. Use of atmospheric elemental size distributions in estimating aerosol sources in the Helsinki area. Atmos Environ 2001b;35:5537-5551.

Paoletti L, Diociaiuti M, De Berardis B, Santucci S, Lozzi L, Picozzi P. Charaterisation of aerosol individual particles in a controlled underground area. Atmos Environ 1999;33:3603-3611.

Powell JJ. Analysis of aluminosilicate particles in biological matrices using histochemistry and X-ray microanalysis. Analyst 2002;127:842-846.

Puledda S, Paoletti L, Ferdinandi M. Airborne quartz concentration in an urban site. Environ Pollut 1999;104:441 -448.

Räisänen M., Kupiainen K., Tervahattu H. The Effect of Mineralogy, Texture and Mechanical Properties of the Antiskid and Asphalt Aggregates on Urban Dust. The Bulletin of Engineering Geology and the Environment 2002; (Accepted to be published).

Rauterberg-Wulff A, Israel GW, Pesch M, Schlums C. Bestimmung des Beitrags von Reifenabrieb zur Russimmision an stark befahrenen Strassen (in German). VDI Berichte 1995; 1228:81-92.

Rogge WF, Hildemann LM, Mazurek MA, Cass GR. Sources of fine organic aerosol. 3. Road dust, tyre debris, and organometallic brake lining dusts: roads as sources and sinks. Environ Sci Technol 1993;27:1892-1904.

Salonen RO, Pennanen AS, Halinen AI, Hirvonen MR, Sillanpaa M, Hillamo R, Karlsson V, Koskentalo T, Aarnio P, Ferguson S, Koutrakis P. A chemical and toxicological comparison of urban air $\mathrm{PM}_{10}$ collected during winter and spring in Finland. Inhalation Toxicol 2000;12(Suppl. 2):95103.

Tiittanen P, Timonen KL, Ruuskanen J, Mirme A, Pekkanen J. Fine particulate air pollution, resuspended road dust and respiratory health among symptomatic children. Eur Respir J 1999;13:266-273.

Venkatram A, Fitz D, Bumiller K, Du S, Boeck M, Ganguly C. Using a dispersion model to estimate emission rates of particulate matter from paved roads. Atmos Environ 1999;33:1093-1102. 